\title{
Shadows and Ghosts of the Hair Matrix: Pilomatrixoma
}

\author{
Anubha Bajaji* \\ Deputy General Manager, India
}

Submission: November 02, 2018; Published: December 06, 2018

"Corresponding author: Anubha Bajaj, Deputy General Manager, LT Foods Ltd, LT Group Company (Daawat Basmati Rice), India

Keywords: Neoplasm; Pilomatrixoma; Sebaceous glands; Epithelial cells; Shadow cells; Calcifying Epithelioma; Hair matrix; Enzyme; Epithelioma; Malignancy; Basal cells

\section{Preface}

The neoplasm, established as the "Calcifying Epithelioma of Malherbe", were scripted as the lesions commencing from the sebaceous glands in the late $19^{\text {th }}$ century (1880) by Malherbe and associates [1]. The histology comprises of the islands of epithelial cells and shadow cells, illustrated in the early $20^{\text {th }}$ century (1922) [2]. "Pilomatrixoma" as a terminology was popularized in the late $20^{\text {th }}$ century (1961) [3] and designated the neoplasm as a derivative of the hair matrix, thus circumventing the term "epithelioma", which may connote a malignancy. The enzyme histochemistry and ultra-structural analysis of the lesion was also computed in the late $20^{\text {th }}$ century (1966) [4], confirming that it originated from the primitive basal cells of the epidermis which differentiate towards the hair matrix.

\section{Analysis and Attributes}

Pilomatrixoma is a derivative neoplasm of the primitive basal cells of the epidermis which diverge into the hair matrix cells $[4,5]$. The lesion is contemporarily classified as a benign skin appendage tumour. Pilomatrixoma (pilomatricoma), previously designated as "Calcifying epithelioma of Malherbe", is a nodular, sub-epidermal, benign tumour emerging from the hair matrix. It preponderantly arises in children and young adults and the majority of the lesions may be situated in the head, neck and upper extremities [4]. Pilomatrixoma may appear as a well circumscribed, solitary, painless, subcutaneous tumefaction. The lesions evolve gradually and lack itching or additional symptoms. The skin over the neoplasm may be unremarkable or may exhibit a pale to reddish blue discoloration. The mobile lesion may adhere to the superimposed skin. Epithelial thinning or superficial ulceration may ensue. The neoplasm is preferentially situated on the face, though unspecified sites may be implicated, except the palms and the soles $[4,6]$. Pilomatrixoma may be detected on a routine clinical inspection. The texture of the lesion is often variable, on account of the incumbent calcification. The ultrasound may depict a typical, completely calcified nodule or a hypo-echoic mass with intrinsic calcification. The contemporary ultrasonic impressions may exhibit five sub-types: Partially calcified, completely calcified, complete \& mixed configuration, pseudo-cystic and pseudotumor [4,7]. A computerized tomography (CT) may be resorted to in patients who demonstrate an extensive tumefaction on the face, especially to distinguish the pre-auricular pilomatrixoma and a parotid gland neoplasm [8]. Pilomatrixoma appears as an estimated $0.1 \%$ of the skin appendage tumours [4]. The tumours preponderantly arise in children and young adults, though no age is exempt. Epidermoid cysts and Lymph node lesions exceed the incidence of Pilomatrixoma, as a tumefaction of the juvenile patients. The median age of tumour appearance is 26.5 years and it varies from the 1-71years. The first two decades enunciate the majority (59.3\%) of the tumors, with a maximal appearance at or before 10 years of age. Gender predominance of the lesion is indeterminate. A Male to Female proportion of 1.24: 1 may be described [4]. The face, neck, upper extremities, trunk and the lower extremities are frequently inhabited by the tumour [6]. The palms, soles and the genitalia may be excluded. The lesion usually varies from $0.5 \mathrm{~cm}$ to $3.0 \mathrm{~cm}$ in magnitude [4].

\section{Histo-Morphology}

A distinct nodule enveloped by a fibrous capsule, situated in the reticular dermis and invading the subcutaneous adipose tissue may be discerned. Pilomatrixoma is represented by islands of cells with a spheroid architecture, marginal basaloid cells with prominent nuclei and a nucleated, centric "shadow" or "ghost" cells the cells, configured in spheroid islands, are composed of a nucleated shadow cells in the midst and basaloid cells in the tumour perimeter [4]. "Shadow cells" also denominated as "Ghost cells", may emerge from basaloid cells and are constituted of extinct cells which are able to conserve the cellular outline with a centric unstained region which coincides with the obscure nucleus. Transitional cells may also appear amidst the basaloid 


\section{Advanced Research in Gastroenterology \& Hepatology}

cells and the ghost cells. Calcification primarily arises in the ghost cell territories. Foreign body giant cell reaction with characteristic giant cells may be enunciated in the region of keratinized debris $[8,9]$. The "ghost" cells may not be restricted to the pilomatrixoma but may be concordant with the epidermoid cysts and chronic dermatitis with hyperkeratosis $[3,4]$. Solid nests of miniature basaloid cells are depicted, which may be misinterpreted as a basal cell carcinoma, especially on a cytological observation. The basaloid cells may be subjected to abrupt keratinization, thereby producing the ghost or shadow cells, which is an essential aspect of the neoplasm [9].

Pigmentation may appear on account of the transplantation of the melanocytes. Foreign body giant cell reaction, ossification and calcification are frequent accompaniments. Extra-medullary hematopoiesis may ensue. Trans-epidermal extrication of the tumor cells or a breach of the superficial epithelium may occur. The histochemical, immune -histochemical and ultra-structural attributes may be concordant with the hair matrix genealogy of the tumor $[9,10]$. However, foci of hair matrix distinction may be exhibited in lesions apart from the pilomatrixoma. Majority of the pilomatrixoma may demonstrate active mutations of the $\beta$ catenin gene CTNNB1 [9].

Pilomatrixoma may also enunciate anomalous histological attributes and a penchant for localized infiltration and reoccurrence, which may be designated as an "aggressive or proliferating pilomatrixoma". Malignant pilomatrixoma (pilomatrix carcinoma) may display cytological atypia, an invasive tumor margin, cellular transformation to squamous cells or clear cells, foci of necrosis and prominent mitosis. Aspects identical to a sarcoma may be detected. On- site reappearance is frequent and metastasis to remote location may ensue [4] (Figure 1-10).

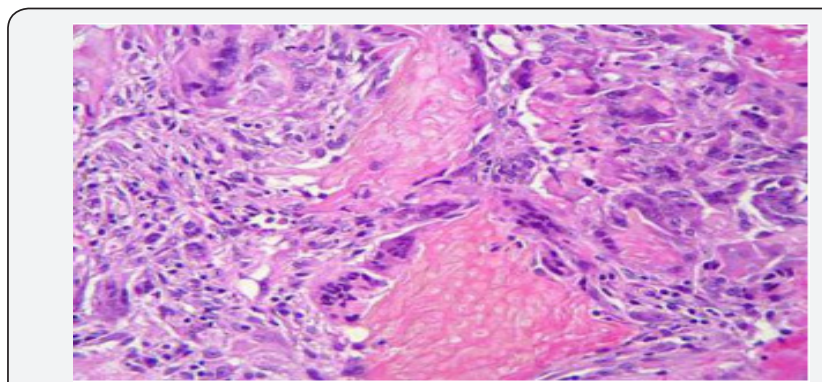

Figure 1: Pilomatrixoma- prominent centric shadow cells.

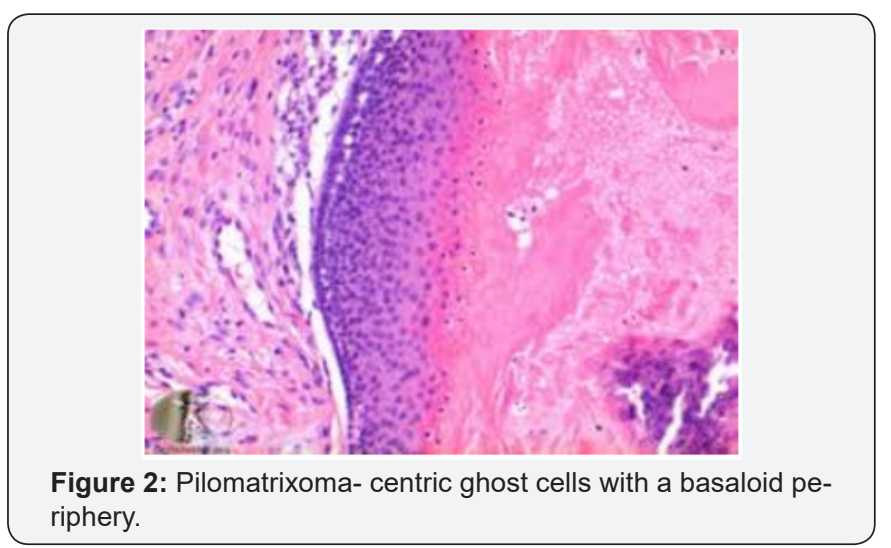

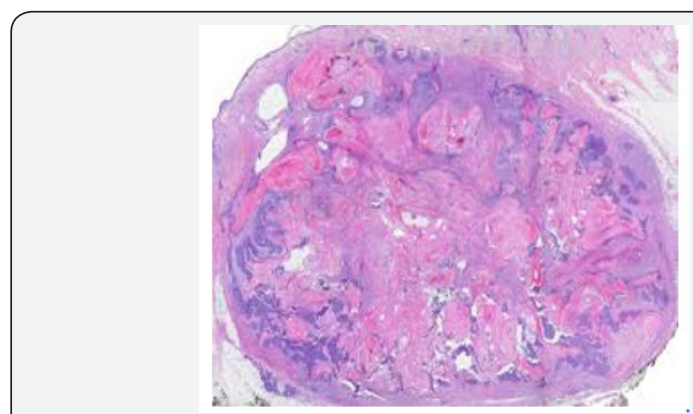

Figure 3: Pilomatrixoma- encapsulated, dimorphic nodules.

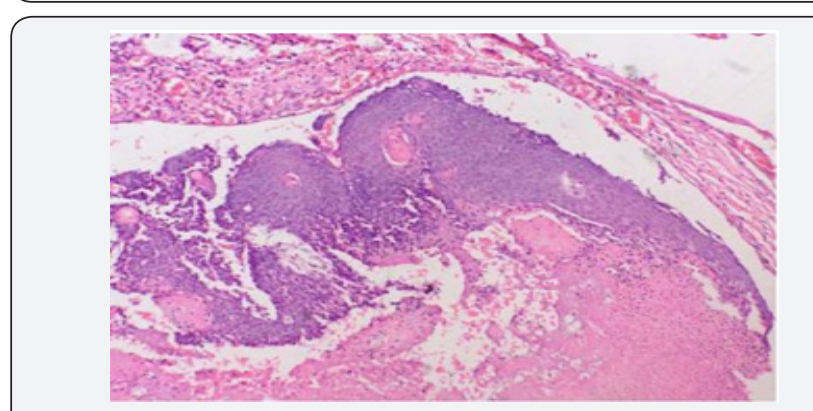

Figure 4: Pilomatrixoma- a basaloid prominence enveloping the shadows.

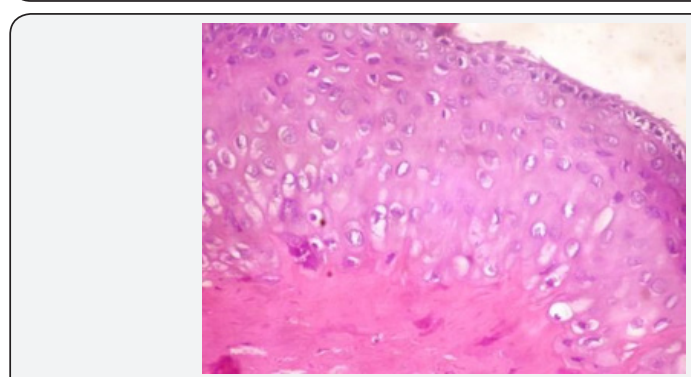

Figure 5: Pilomatrixoma- ghost cells with marked acanthosis.

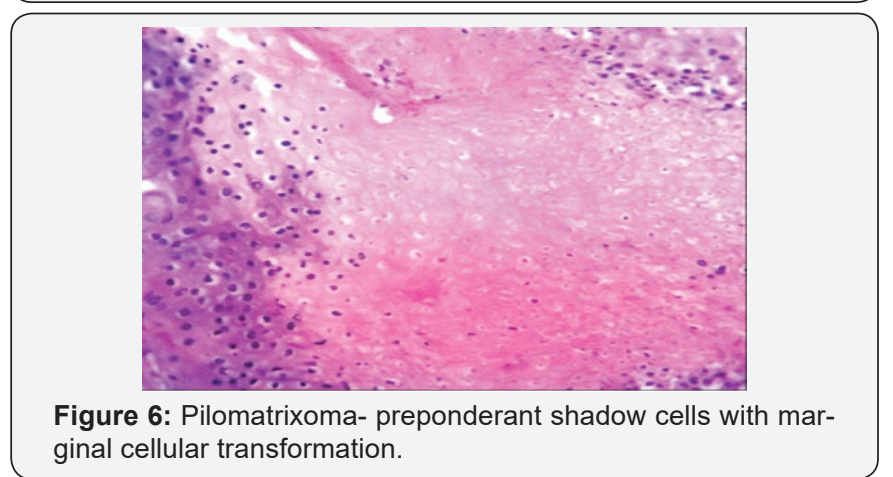

ginal cellular transformation
ginat

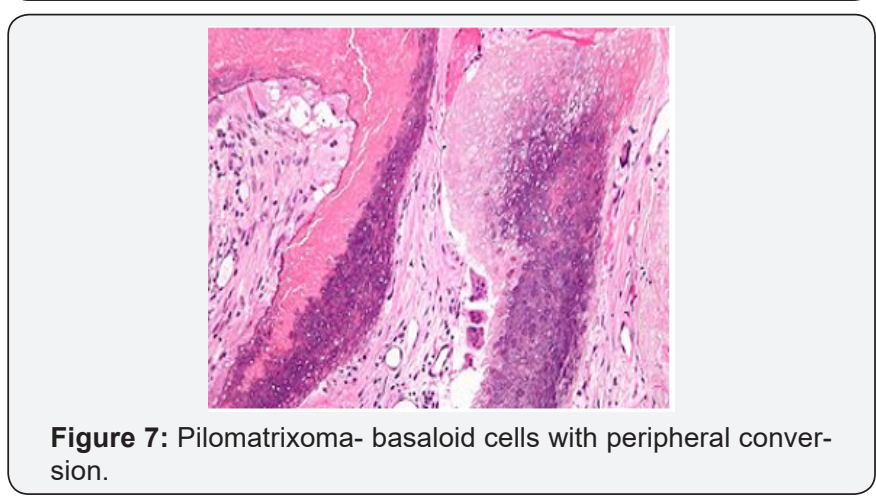



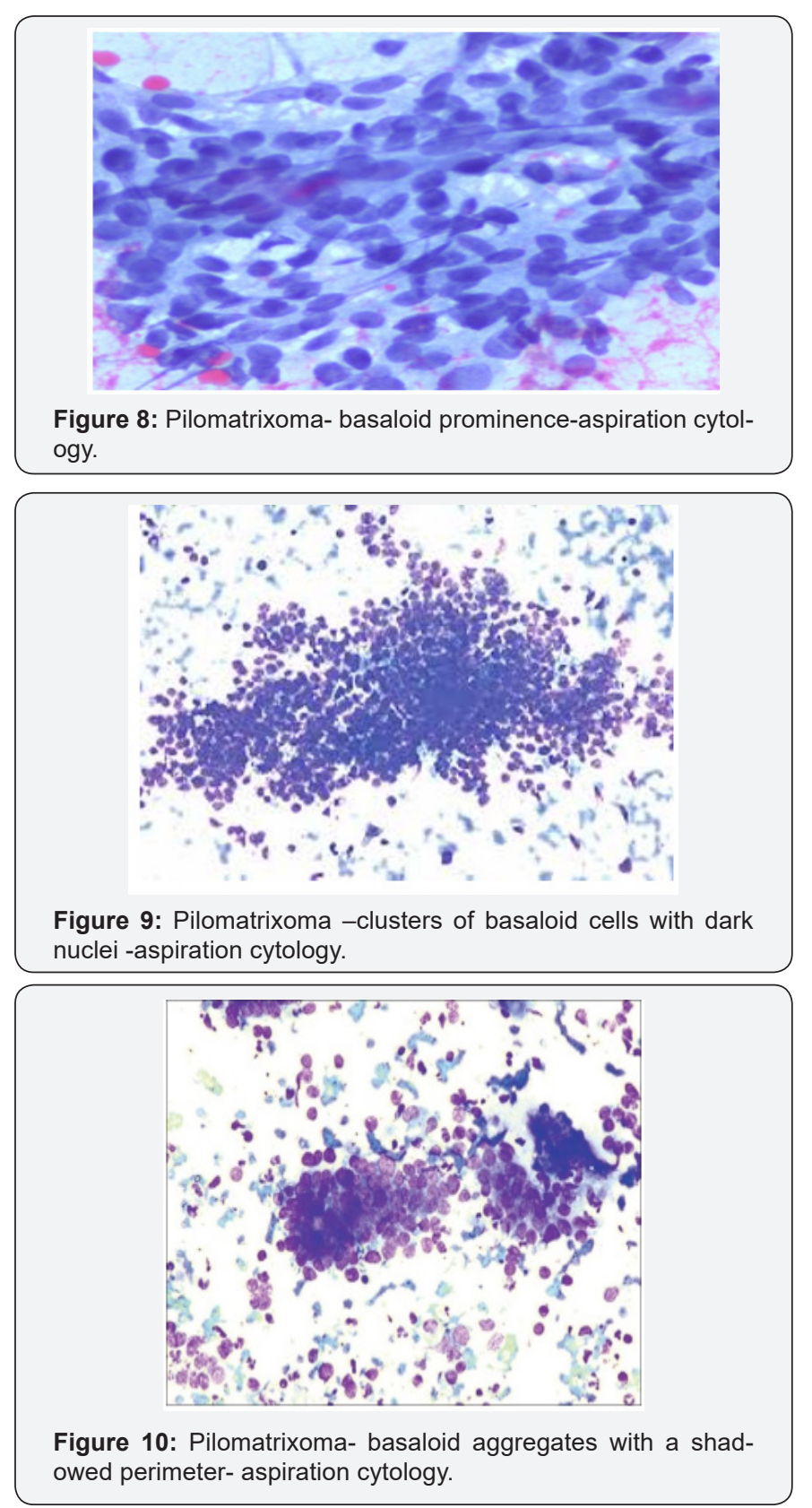

\section{Adjunctive Aspects}

The aetiology and pathogenesis of the condition has been related to the mutations of CTNNB1 genes, which ensures the encoding of $\beta$ catenin and executes the normal hair genesis [11]. A trisomy 18 may be a cytogenetic aberration in the neoplasm [12]. Pilomatrixoma may also be accompanied by myotonic dystrophy (Steinert disease), Gardner's syndrome, Turner's syndrome, Rubinstein- Taybi syndrome and Soto syndrome. In addition, 21 hydroxylase deficiency, trisomy 9, MYH polyposis, celiac disease, xeroderma pigmentosum, sarcoidosis and angiomyxoma may also be delineated $[4,13]$.

Chronic disorders may not associate with the lesion. However, a concordance with hyper-calcemic and an amplified parathyroid hormone related protein [14] may be demonstrated. Pilomatrixoma is primarily diagnosed by a comprehensive clinical observation. The percentage of a precise pre-operative discovery of the tumefaction varies from $0 \%$ to $30 \%$ on account of innumerable probable conditions requiring a distinction such as the dermoid cyst, epidermoid cyst, branchial cyst, lipoma, preauricular sinus, diverse lymph node enlargement, hemangioma and foreign body giant cell reaction [4]. The clinical and diagnostic accuracy may be achieved in $19.7 \%$ instances. The commonest diagnostic misinterpretation may be a carcinoma (12.1\%) followed by the epidermoid cyst (9.1\%). Pilomatrixoma may display micro-calcification on mammography and may simulate a breast carcinoma [15].

Imaging modalities such as the ultrasound (US) or the computerized tomography (CT) are minimally applicable and may especially be employed to distinguish the pre-auricular masses, the parotid gland tumours or for the interpretation of aggressive lesions [8] Fine needle aspiration, when depicting an abundance of shadow or ghost cells, may be accurately interpretative. Nevertheless, the absence of shadow cells may engender a false negative diagnosis or a misrepresentation of a pilomatrix carcinoma [16]. Multitudinous pilomatrixomas may be exceptional and may amount to an estimated $24 \%$ instances with an accompaniment of cited genetic disorders, the concurrence of which may be suggestive of the neoplasm. A clinical interpretation of the "Kabuki syndrome "with infrequent, manifold, congenital anomalies or mental retardation of obscure origin may be elucidated [4] Tumor relapse following surgical eradication is infrequent and a reappearance rate may be at an estimated 2-6\% [17].

Tumour recurrences may imply the emergence of a pilomatrix carcinoma, a malignant category of the pilomatrixoma. The malignant transformation may be indicated by clinical or morphological aspects such as elderly individuals, male gender, tumour progression, tumour adherence to abutting architecture, skin infiltration, indistinct tumour perimeter, capsular rupture with tissue ingress, enhanced mitotic activity, cellular and nuclear atypia, central necrosis and alterations in the lymphatic and vascular channels $[6,18]$. Metastasis frequently appear in the lung, bones, brain, abdominal organs, skin and lymph nodes [17]. An estimated $1.8 \%$ of the patients may delineate a reoccurrence within 3 months of the surgical intervention. The specific disorder may be termed as the "proliferating pilomatrixoma “. The histopathology may demonstrate atypical cells with hypertrophic nuclei and numerous mitotic figures. The lesion may be comparatively symmetrical or may configure conformable lobules comprising of basaloid cells and may lack a perineural or lymphatic ingress thereby affirming a benign condition. The particular derivative may not be a harbinger of a malignant pilomatrixoma. The preferred therapy may be a total surgical excision, as the lesion may not spontaneously regress. One $\mathrm{cm}$ of the uninvolved tissue may be removed with the lateral margin by local excision as it is fundamental to minimizing localized reoccurrence. The eradication of the skin circumscribing the tumour is a pre-requisite to the surgical excision, as the neoplasm tends to attach to dermis [4]. 


\section{Advanced Research in Gastroenterology \& Hepatology}

\section{References}

1. Malherbe A (1880) Note Sur L' epitheliome calcific des glandes sebacces. Prog Med 8: 826-837.

2. Dubreuilh W (1922) De L' epitheliome calcific etude histologique. Ann Dermatol Syphilol 3: 257-268.

3. Forbis RJ Jr, Helwig EB (1961) Pilomatrixoma (calcifying epithelioma) Arch Dermatol 83: 606-618.

4. Rebeca Fonseca, José de Souza, Izabella Costa Araujo, Aloísio Ferreira Nárlei Amarante, et al. (2012) Pilomatricoma Calcifying epithelioma of Malherbe. Rev Bras Cir Plast 27(4): 605-610.

5. Hashimoto K, Nelson RG, Lever WF (1966) Calcifying epithelioma of Malherbe: Histochemical and Electron Microscopic studies. J Invest Dermatol 46(4): 391-408.

6. Guinot-Moya R, Valmaseda-Castellon E, Berini-Aytes L, Gay-Escoda C (2011) Pilomatrixoma: a review of 205 cases. Med Oral Patol Oral Cir Bucal 16(4): e552-555.

7. Solivetti FM, Elia F, Drusco A, Panetta C, Amantea A (2010) Epithelioma of Malherbe: new ultrasound patterns. J Exp Clin Cancer Res 6: 29-42.

8. Lan MY, Lan MC, Ho CY, Li WY, Lin CZ (2003) Pilomatrixoma of head and neck region: a retrospective review of 179 cases. Arch Otolaryngol Head and Neck Surgery 129(12): 1327-1330.

9. Rosai and Ackerman's (2011) Surgical Pathology. (10 ${ }^{\text {th }}$ edt), pp. 150.

10. Aly Z, Pozo L, Diaz-Cano SJ (2006) Colonization of epithelial pillar neoplasm by melanocytes. Histopathology 48(2): 213-217.

This work is licensed under Creative

Commons Attribution 4.0 License

DOI: 10.19080/ARGH.2018.11.555823
11. Rousselot C, Tourasse C, Samimi M, Degand P, Dénier JF, et al (2007) Breast pilomatrixoma manifesting on microcalcification on mammography: report of two cases. J Radiol 881(7-8 Pt I): 978-980.

12. LeBoit PE, Parslow TG, Choy SH (1987) Hair matrix differentiation: Occurrence in lesions other that Pliomatricoma. Am J Dermatopathol 9(5): 399-405.

13. Agoston AT, Liang CW, Richkind KE, Fletcher JA, Vargas SO, et al. (2010) Trisomy 18 is a consistent cytogenetic feature in pilomatrixoma. Mod Pathol 23(8): 1147-1150.

14. Papadavid E, Mistidou M, Katoulis A, Zambacos G, Stavrianeas N, et al. (2010) Familial occurrence of calcifying epithelioma of Malherbe. Int J Dermatol 49(12): 1456-1457

15. Kambe Y, Nakano H, Kaneko T, Aizu T, Ikenaga S, et al. (2006) Giant Pilomatrixoma associated with hypercalcemia and elevated levels of parathyroid hormone related protein. Br J Dermatol 155(1): 208-210.

16. Autelitano L, Biglioli F, Migliori G, Colletti G (2009) Pilomatrix carcinoma with visceral metastasis: case report and review of literature. J Plast Reconstr Aesthet Surg 62(12): e574-577.

17. Wang J, Cobb CJ, Martin SE, Venegas R, Wu N, et al. (2001) Pilomatrixoma: clinico-pathologic study of 51 cases with emphasis on cytologic features. Diagn Cytopathol 27(3): 167-172.

18. Brenn T (2005) Pathology of skin. ( $3^{\text {rd }}$ edn), Philadelphia Elseiver, pp. 1536-1539.

\section{Your next submission with JuniperPublishers} will reach you the below assets

- Quality Editorial service

- Swift Peer Review

- Reprints availability

- E-prints Service

- Manuscript Podcast for convenient understanding

- Global attainment for your research

- Manuscript accessibility in different formats

(Pdf, E-pub, Full Text, audio)

- Unceasing customer service

Track the below URL for one-step submission

https://juniperpublishers.com/online-submission.php 